\title{
German unity threat to space spending
}

\section{- New government reviews space policy - Physicists condemn spiralling costs}

\section{Munich}

THE rumblings about Germany pulling out of the European manned space flight programme became louder last week, as politicians indicated that critical decisions on the space policy of the newly united country will be made in the next six weeks and the reunified German Physical Society (DPG) launched a stinging attack on the programme's scientific merit.

At stake is at least one of the three pillars of the European manned space flight programme, Columbus, which will form a module of the US space station Freedom. The Germans have a 38 per cent stake in Columbus. France has taken the lead in the other two projects: the space shuttle Hermes and the heavy payload rocket Ariane 5.

If the expected costs for the three projects rise more than 20 per cent from the original estimates, which they are quite likely to do, European Space Agency (ESA) member states have the option to withdraw. The 13 member states will meet to discuss the three projects by June 1991 .

At the very least, Germany is planning to demand the 'stretching' of the Columbus programme over a longer period in order to spread the cost. The cost of the three projects, estimated in 1987 at DM21,000 million ( $\$ 14,190$ million), has now risen to an estimated minimum of DM30,000 million.

"We have to ask ourselves whether it is good for Germany" to continue with the manned space flight programme, says parliamentary research committee member Heinz Seesing of the Christian Democratic Union (CDU), which with two smaller parties won a clear majority in elections on 2 December. Bearing in mind the uncertainty caused by the cost of German reunification, "we have to ask ourselves if we wouldn't be better off spending our money on microchips", adds Seesing. Nevertheless, he emphasizes that the final decision has yet to be made.

Seesing expects the position to be clarified during the coalition negotiations which are due to be completed by the end of January. The election "changed the face" of the parliament, he says. There are more than a hundred new members from eastern Germany who may not see the point of sending men into space while unemployment rockets at home.

Another parliamentarian, Jürgen Rüttgers, CDU space policy spokesman, says that the decision on Columbus will strongly depend on the changes that NASA (US National Aeronautics and Space Administration) makes in the plans for space station Freedom following the critical report on NASA's activities by the Augustine Commission published last week (see Nature 348, 569,1990). For example, if the power available for Columbus were to be reduced by half, as has been discussed, then it might be "less sensible" for Europe to build it. "Figuratively speaking", says Rüttgers, "if NASA lets us use the module for only half the day, then we have to ask if the whole project makes sense."

In the case of Hermes, Rüttgers says that Germany will wait for France to take the intitiative in maintaining the current programme or reducing it to a technology project, focused perhaps on hypersonic transport instead of shuttling astronauts into space. "We will not pull out", he says. But of course if Columbus is reduced or eliminated, Hermes will lose its main raison d'être.

Smelling blood for the first time in its behind-the-scenes battle against manned space flight, the science community, led by the DPG, decided to make public its concern. It issued a damning broadside in the form of a memorandum condemning further German participation in the projects if the costs indeed rise by more than 20 per cent.

DPG urged politicians to stop arguing that science and industry will be the main beneficiaries of a decision to establish an independent manned space programme. A poll of DPG members, including those involved in microgravity research, which is often named as a potentially important user of the space station, revealed that the "overwhelming majority" opposed going further with the manned space programme, says Erhard Keppler, a coauthor of the memorandum and a physicist at the Max Planck Institute for Aeronomy.

As in the United States, researchers are mainly worried about money drying up for Earthbound research. They claim that the cost of space-based research is disproportionate to its benefits. Keppler says that Germany will have to pay as much as DM2,000 million a year just to keep Columbus in operation (the government estimates DM1,000 million), a huge amount compared with an annual 'basic research budget' Keppler estimates at DM16,000-17,000 million.

Rüttgers replies that such an

\section{Poland to join strike-disrupted CERN} London

POLAND will become the sixteenth full member of CERN, the European particle physics centre in Geneva, in July 1991 the first of the newly democratic countries of Eastern Europe to join the organization.

Taking account of the country's severe economic difficulties, CERN's governing council decided last week that Poland should initially pay only SFr1 million (about $£ 400,000$ ) a year towards CERN's running costs. But the Polish contribution will increase to about 1.2 per cent of the total budget (SFr868 million in 1991) by 2000. Czechoslovakia, Hungary and Yugoslavia are also interested in joining CERN.

But CERN experiments may be disrupted by industrial action next year, after the council refused to agree salary increases for CERN staff beyond a 2 per cent increase in real terms in the coming year. The staff association is fighting for a 6.4 per cent increase by 1993 , and has already introduced a work-to-rule (see Nature 348, 379; 22 November 1990), now suspended, and staged a number of two-hour strikes. Henry Atherton, vice-president of the staff association, says CERN staff are now considering what action to take during the next round of pay negotiations, which begin in the summer.

Peter Aldhous

"unpolitical" argument "could only come from professors". There is no requirement for this money to come out of the Research Ministry budget, he says. Rüttgers believes that Research Minister Heinz Riesenhuber (CDU) will keep his promise not to let the space programme take up more than 22 per cent of the ministry's budget. At present, the figure stands at 20 per cent.

Keppler condemned the idea of 'stretching' the space projects over a longer time, because he says that it would make the "mid-1980s" technology, which he calls "the junk from the day before yesterday", even more obsolete by the time it arrived in space.

According to Rüttgers, the physicists are increasingly being joined by politicians in debating manned space flight in terms of its scientific merits instead of just talking about the desirability of "putting more Germans into space". He adds: "Manned space flight is not a dogma".

Rüttgers discounted the possibility that Germany would turn to the Soviet Union for more cooperation in space if the United States reduces its space programme. "The Soviets have a space station and a big rocket and they can put men in space", he says. "So what? We still have to ask ourselves why we want them there."

Steven Dickman 